\title{
KEJAWEN [JAVANESE SUFISM] AND PERENNIAL PHILOSOPHY IN KUNTOWIJOYO'S KHOTBAH DI ATAS BUKIT
}

\section{By Mohd. Faizal Haji Musa}

[tehranifaisal@yahoo.com]

Akademi Seni Budaya dan Warisan Kebangsaan [ASWARA]

\begin{abstract}
Khotbah di Atas Bukit (Sermon on a Hill) by Kuntowijoyo was written to foreground transcendental principles, in accordance with the Theory of Transcendental Literature. Transcendental principles are brought to the fore and applied in this work through the use of symbolism. Kuntowijoyo uses a local subject for enquiry, kejawen (Javanese sufism), to address issues of faith and tauhid (Islamic Monotheism or the Oneness of Allah). However, there is some ambiguity in the text which could affect the aspects of tauhid discussed. In presenting the teachings of Sufism, Kuntowijoyo may in the process be misunderstood and consequently considered to subscribe to global theology where tauhid is simplified and religions "combined". Khotbah di Atas Bukit is a complex work to read because of the overuse of symbolism aimed at obscuring meaning. This kind of symbolism needs to be explained, particularly to readers who have little knowledge of sufism. It is this that makes Khotbah di Atas Bukit a specialized work for a specialized readership.
\end{abstract}

Key words: Islamic literature, Islam kejawen, sufism, perennial philosophy, Islamic leadership, tauhid, Kuntowijoyo, pluralism, 


\section{MALAY LITERATURE}

mysticism, Transcendental Literature, myth, global religion, orthodox Muslims (the faithful).

\section{Introduction}

Tauhid (Islamic Monotheism or the Oneness of Allah) is the most important issue discussed in Islamic literature. It is unanimously agreed that tauhid is the very basis of Islamic literature. In Islam, tauhid is considered to be the solution to a variety of human problems. As literature usually discusses the problems of mankind and the solutions to them, tauhid is often referred to and drawn on as the problem-solving formula in Islamic literature.

In addition to this, the issue of tauhid in Islam also often concerns iman (faith). Islam stresses that faith must come from understanding, wisdom and knowledge. Iman is not about believing in knowledge whose source is unknown or blindly following what others are doing. Therefore, iman acts as a yardstick which helps us recognize deviant beliefs, moral wrongdoings and falsehood. This is stated in the Qur'an in Surah (Chapter) al-Imran, verses 190-93, which can be translated as:

Verily! In the creation of the heavens and the earth, and in the alternation of night and day, there are indeed signs for men of understanding. Those who remember Allah (always, and in prayers) standing, sitting, and lying down on their sides, and think deeply about the creation of the heavens and the earth, (saying): - Our Lord! You have not created (all) this without purpose, glory be to You! (Exalted are You above all that they associate with You as partners). Give us salvation from the torment of the Fire. Our Lord! Verily, whom You admit to the Fire, indeed, You have disgraced him; and never will the Zalimun (polytheist and wrongdoers) find any helpers. Our Lord! Verily, we heard the call of one (Muhammad SAW) calling (us) to Faith. "Believe in your Lord," and we have believed. Our Lord! Forgive us our sins and expiate from us our evil deeds, and make us die (in the state of righteousness) along with Al-Abrar (the pious believers of Islamic Monotheism).

Faith is often linked to righteous deeds. In verse 9 of Surah Yunus, Allah SWT says (which can be translated as):

Verily, those who believe, and do deeds of righteousness, their Lord will guide them through their Faith. 
Abu'l A'la al-Maududi (1985:29) stresses that tauhid, being the very core of Islamic teachings, is related to the submission of man (Allah's humble servants) to Allah, and their obedience of His laws and decrees'.

Abdul Latif Muda and Rosmawati Ali (1998:12-13) meanwhile explain that tauhid is the heart of Islamic teachings. The essence of tauhid shapes and formulates a system of life and laws governing the relationship between man and man, man and Allah, and man and his environment. In other words, tauhid is an ideology that determines the lives of human beings in all aspects, including the arts and literature.

Apart from this, the concept of tauhid is very closely linked to prophethood. In this respect, al-Maududi (1985:57) emphasizes that the main purpose of prophethood is to oppose and eliminate transgressions, falsehoods and all forms of evil in order to establish human values that are beneficial to human life ${ }^{1}$.

The concept of tauhid is also closely linked to the issue of leadership. The close relationship between leadership and tauhid is an important issue which concerns the Hereafter. The Holy Qur'an refers to leadership through tauhid as the Authority of God. In contrast to the Authority of God is the authority of "taghut (false gods) and satan". According to the Qur'an, the "authority of taghut (false gods) and satan" is haram (forbidden). In explaining the "authority of taghut and satan", verses 115-20 of Surah al-Nisa', can be cited for further clarification. Allah's command can be translated as:

And whoever contradicts and opposes the Messenger (Muhammad SAW) after the right path has been shown clearly to him, and follows other than the believers' way, We shall keep him in the path he has chosen, and burn him in Hell,- what an evil destination! Verily! Allah forgives not (the sin of) setting up partners (in worship) with Him, but he forgives whom he wills, sins other than that, and whoever sets up partners in worship with Allah, has indeed strayed far away. They (all those who worship other than Allah) invoke nothing but female deities besides Him (Allah), and they invoke nothing but Satan, a persistent rebel! Allah did curse him. And he (Satan) said: "I will take an appointed portion of your slaves. Verily, I will mislead them, and surely, I will arouse in them false desires; and certainly, I will order them to slit the ears of cattle, and indeed I will order them to change the nature created by 


\section{MALAY LITERATURE}

Allah." And whoever, takes (Satan) as a Wali (protector or helper) instead of Allah, has surely suffered a manifest loss. He (Satan) makes promises to them, and arouses in them false desires; and Satan's promises are nothing but deception.

Based on these verses, the authority and leadership of satan and his followers clearly results in man enjoying only restrictive freedom. Infidelity (to the Creator) will only lead man astray and plunge him into darkness (Abdul Hadi Awang 2003:148-83). ${ }^{2}$

Leadership, as it is meant here, is not limited to leadership in politics, rather it encompasses leadership in spiritual, intellectual and religious guidance, as well as guidance in every aspect of life. A leader who has gone astray will provide the wrong guidance which will adversely affect tauhid in a serious way. Without the right kind of leadership, it will be futile to offer tauhid as the solution in literary works, for instance. In this respect, what the Qur'an terms as "meaningless" or abath refers to pointless, illogical actions which do not bring any benefits. Allah says in verses 16-17, Surah alAnbiya' which can be translated as:

We created not the heavens and the earth and all that is between them for a (mere) play. Had We intended to take a pastime (i.e a wife or a son), We could surely have taken it from Us, if We were going to do (that).

Allah also says in Surah Muhammad, verse 36, which can be translated as:

The life of this world is but play and pastime; but if you believe (in the Oneness of Allah - Islamic Monotheism), and fear Allah and avoid evil, He will grant you your wages, and will not ask you your wealth.

Another verse that can be cited as evidence is verse 32 of the Chapter al-An'am, which can be translated as:

And the life of this world is nothing but play and amusement. But far better is the house in the Hereafter for those who are AlMuttaqun (the pious). Will you not then understand?

It is clear that "la'ibun wa lahwun" "play (or pastime) and amusement" mentioned in these three verses are rejected in the 
Qur'an as this goes against the purpose of human life, that is, to prepare for life in the hereafter and to totally submit to Allah.

Leadership as one of the underpinnings of the concept of tauhid, is dominant in the novel Khotbah di Atas Bukit, written by Kuntowijoyo (2000) from Indonesia and published by Yayasan Bentang Budaya. This novel, directly and indirectly, discusses the theme leadership based on tauhid. The discussion that follows is divided into four parts: the first is a synopsis of Khotbah di Atas Bukit; the second, a discussion of the textual composition of Khotbah di Atas Bukit; the third, a discourse on tauhid in Khotbah di Atas Bukit, that is, the issue of perennial philosophy; and lastly, the conclusion.

\section{A Synopsis of Khotbah di Atas Bukit}

Kuntowijoyo's novel Khotbah di Atas Bukit (2000) is an important work to discuss as the late Kuntowiiyo was the first writer to introduce the concept of Transcendental Literature in Indonesia. This novel revolves around a wealthy former government officer, Barman, who marries Popi, a young sexy beguiling girl, who becomes his companion as he lives out the remainder of his life in a hilly countryside. However, Barman is impotent and is unable to fulfill his conjugal responsibilities. This causes Barman to feel stressed. He coincidentally meets an old man named Humam on top of a hill near his vacation home. There is no description of Humam's background and his character is killed off in the middle of the novel. The chance meeting results in Barman, who is enchanted with the mystery surrounding Humam, striving to search for and ponder on a number of central issues concerning life, which Humam had earlier raised. At the end of the novel, Barman dies tragically and meets his "true love".

What stands out in this text is its main character who is shrouded in mystery and involved in a sufic quest to discover and understand the true existence of Allah. The text also examines the question of leadership or walayat (authority). Khotbah di Atas Bukit, for example, portrays the protagonist Barman, who is left without a leader when he loses Humam (upon the latter's death). Thus, the writer of this paper is of the opinion that Kuntowijoyo's discourse on the concept of tauhid makes for an interesting analysis. 


\section{The Textual Composition of Khotbah di Atas Bukit}

As mentioned earlier, Khotbah di Atas Bukit by Kuntowijoyo is an important novel to discuss as the late Kuntowijoyo was the first writer in Indonesia to address the theory of Transcendental Literature. The Theory of Transcendental Literature embodies a number of unique characteristics. Kuntowijoyo outlines the themes of literary works founded on this theory as "humanisation" (amar ma'ruf), "liberation" (nahi mungkar) and "transcendence" (faith in Allah). This theory does not stipulate any specific literary forms but Kuntowijoyo himself, as the pioneer, rejected the form sermon, long factual accounts and a direct writing style as characteristics of "Transcendental Literature". A specific criterion of the Transcendental theory is the interplay of symbols in literary works; the interpretation of their meanings are left to the reader. The truth is camouflaged by these symbols, and the symbols themselves are the essence of the beauty of a piece of writing. Kuntowijoyo places much importance on the writer's unfettered imagination and encourages the employment of "inclusivism" (the admission of external elements) in literary works. As Kuntowijoyo does not specify any particular "external elements", both local and foreign sources may therefore be tapped. By local sources meant here is the spiritual tradition of the great religions, the Javanese culture including the traditions and belief sytems of the Javanese, as well as sufi teachings. (Kuntowijoyo, 2003).

In the context of Indonesia, specifically that of Java, the spread of Sufism had led to the emergence of kejawen, also known as "Javanese Sufism". Literature is used as a vehicle to spread the teachings of kejawen.

To understand what is meant by the teachings of kejawen, it must first of all be explained that Islam was spread to all corners of the earth after the passing of Prophet Muhammad SAW, using two approaches: a compromising approach and a non-compromising approach. The non-compromising approach was adopted in much of West Asia. Dakwah Islamiyyah or the spread of Islam encountered a clear and sharp dividing line. The dividing line meant here is the distinction between pre-Islamic beliefs and practices, and Islam that is without compromise. This means that there was no compromise in spreading Islam, and that all pre-Islamic customs and practices that 
were against the teachings of Islam were abandoned and eliminated. Terms and concepts such as iman (faith), mushrik (polytheist, pagan) and kufur (infidelity) were used in spreading Islam. The second approach, one of compromise, was used to spread Islam in Africa, Central Asia and the Malay Archipelago. This approach meant that the teachings of Islam were "intermingled" or "combined" with other teachings and traditions, some of which sometimes were contrary to the Islamic identity. To facilitate the acceptance of Islam among the local populace, the customs and traditions of pre-Islamic times were not totally discarded. In fact, some pre-Islamic customs and traditions were allowed to coexist with Islamic teachings. This kind of intermingling and compromise produced a value system that was in nature "syncretic".

According to a scholar, Simuh (1995:155-63), who has done a lot of research on kejawen, the sufi approach to spreading Islam in the Malay Archipelago had produced "a unique blend of Islam". He adds that "Sufic Islam" which had spread throughout this region, was "a product of a compromise between Islam and mysticism". Thus, according to him, Islam willingly coexisted with "the local socio-cultural traditions". In order to have a better understanding of this issue, it is important to first of all understand the position of the santri (devout Muslims) and abangan (Muslims who do not quite practice the religion, non-practising Muslims) and their link to literature.

When Islam was first introduced in Java, it found itself on a collision course with Hinduism which had a strong foothold there. The "Javanese Hindu" tradition was safeguarded by two groups. The first was the traditional priyayi (nobility) which Muslim missionaries found difficult to penetrate; the second, the traditional group wong cilik or the common folks, who clung to animistic-dynamic beliefs. Both groups had come into contact with the Islamic missionaries. This encounter resulted in the formation of two groups within the society known in Indonesia as santri and abangan ${ }^{3}$.

Zaini Muchtarom (1988:2), who examines this issue explains that the emergence of Islam in Java was much aided by the kiyai (religious teachers) and ulama (Islamic scholars) whom the santri consulted. The influence of these groups, in the beginning, was limited to the trading centres along the coastal regions, but later spread to the more remote areas of Java. After the Islamic 
missionaries succeeded in penetrating the Javanese villages and more religious schools were set up, a devout Muslim community started to evolve. Zaini describes this group as "people who were educated by the pesantren, and in turn were able to teach Islamic worship and the Qur'an". At the same time, however, there were areas in Java where Islam was slow to spread due to the strong influence of Hinduism. Therefore, missionaries, at that time, were forced to use the method of compromise (Zaini Muchtarom, 1988: $23)^{4}$. The marriage of Islamic teachings with the local cultures resulted in what is known as kejawen. Followers of this teaching are referred to as abangan.

Simuh, in citing Clifford Geertz, writes "the mystical school of thought, or kejawen" (and its followers the abangans) was accepted as an Islamic school of thought in Java. Simuh adds that the teachings of kejawen and Sufism have some basic similarities. Mysticism is a part of kejawen. The first type of mysticim, "mysticism of infinity", is called lir sarah aneng lautan (human beings are like foam in the sea) in this teaching. The second type of mysticism, "mysticism of personality", is also found in kejawen and it refers to the hubungan kawala dengan Gusti' (the relationship between the servant and his Lord). Simuh (1995:37-50) explains that the first type of mysticism was practised, among others, by famous sufi writers such as Ibnu Arabi, Hamzah Fansuri and Shamsuddin Pase, while the second type of mysticism was practised by Imam al-Ghazali ${ }^{5}$.

Apart from the aspects of kejawen explained above, Transcendental Literature is very often linked to Sufism. According to Kuntowijoyo, the use of symbols is mandatory in the theory of Transcendental Literature. These symbols need to be interpreted by the reader in order for him to understand the message the writer wishes to convey. The use of symbolism, as mentioned above, is highlighted by Kuntowijoyo in his novel Khotbah di Atas Bukit. It is therefore not surprising that the novel exemplifies the use of symbolism. It is common knowledge that symbolism is linked to Sufism and literature related to Sufism. Muhammad Bukhari Lubis (1997:100), a scholar who studied in great depth the sufic literature of Persia, Turkey and the Malay world, cites al-Awadi and explains that sufi writers have the uncanny tendency to use symbols in their writings:

Al-Awadi writes: The atmosphere of tasawuf (sufism) which this 
poem attempts to create, is itself full of obvious ambiguity. This is because words expressed directly cannot fully explain this mood. Sufis tend to generate this atmosphere using abstract symbols which conceal meaning that is enshrouded by external words, and can only be understood by those who deserve to know.

In addition, the use of symbols in literature containing sufi teachings is also known as a shathiyat ${ }^{6}$ rendition or mystical expression (S.M. Zakir, 2000:101-06). Ibnu Arabi, for example, was responsible for bringing the expression of style, that is shath, into the intellectual world. A Khurasan sufi, Abu Nasr al Sarraj, had further developed this idea of shath. It must be mentioned that shath only occurs after a sufi has undergone several processes of purification and meaning interpretation, where the climax is the total eradication of the ego, and the result, the birth of a pure soul. Owing to this, a famous sufi, Sarraj, once said that shath is like "water brimming over the edge" due to the union of man and his Creator. In this state of being "intoxicated" with the true nature of God and one's purified soul, expressions will pour forth in the form of symbols or mutashabih (Ernst and Nasr, 1994:5-18).

In line with this too, the teachings of some tareqat (religious sects) within Sufism, for example, stress the use of alphabetic symbols ${ }^{7}$. Such sufic symbols can be found in classical Malay works such as Hikayat Nur Muhammad. Birds, for example, symbolize the soul, to the extent that some sufic principles are expressed using these symbol' (Baharudin Ahmad, 2003:476).

Against the background of this argument, and as a novel that characterizes Sufi teachings, Khotbah di Atas Bukit is seen to be inclined towards symbolism. In this novel, the employment of symbolism is executed through its characters and characterization. For example, Popi is depicted as a beautiful, young, sexy woman who is very much loved by Barman. Apart from this, the character's name, Popi, can be easily linked to opium (poppies). In the context of the structuring of a novel, her name and the depiction of her character as described above indicate that Popi symbolizes the material world and enjoyment. The character Humam, meanwhile, is depicted as being full of mystery; often using philosophy in order to communicate, is knowledgeable and calm. The qualities assigned to the character Humam show that he symbolizes a "spiritual dimension", specifically, sufism. Between the two characters, each of which is 


\section{MALAY LITERATURE}

endowed with his or her own symbols, Kuntowijoyo created Barman as the protagonist in this novel. Clearly, the novel portrays Barman as a character trapped within two worlds, and subsequently demands that he makes his choice. It is within this context that Barman and his actions can be interpreted as a "quest". The fact that Barman ascends a hill in order to find peace after retirement, strengthens the contention that this character represents a fundamental quest. The consolidation of the elements of character and characterization as discussed above, is part of the novel's effort to highlight the theme of sufism.

In line with the symbolism of the characters and their characterization is the use of the setting which is also consolidated to bring out the theme of sufism in the novel Khotbah di Atas Bukit. The detailed description of the hilly area serves to enable sufi teachings to be symbolically injected into the novel. The excerpt below is evidence of this:

Alam ialah yang maha besar. Kita hanya bagian-Nya. Jangan sedih atau gembira. Kembalilah ke sana. la akan menerima kehadiranmu." Lalu ia akan membangunkannya betul-betul dan ketika Barman menggosok matanya untuk mengenal kembali ke tempat itu ia akan berteriak keras: "Inilah kelahiranmu yang kedua! Dalam kebebasan sejati, semurni-murninya. Seperti udara gunung, seperti air mengalir dari mata air, seperti burung-burung di udara." la akan berteriak keras, keras. Sungguh itu akan dikerjakannya. (Kuntowijoyo, 2000:81-81)

"Nature is that which is most great. We are only a part of It. Be neither sad nor happy. Return to it. It will welcome you." Then he will wake it up completely and when Barman rubs his eyes to try to make out the place, he shouts at the top of his voice, "This is your second birth! In the true essence of freedom, as pure as can be. Like the mountain air, like water that flows from a spring, like the birds in the sky." He will shout loudly, loudly. Truly, that is what he will do. (Kuntowijoyo, 2000:81-82)

In the above depiction of nature lies an invitation to man to be like "the mountain air", "the flowing water" and "the birds in the sky", which clearly lends a certain meaning to human life.

The combining of such symbols causes us to conceive a more basic meaning in the novel Khotbah di Atas Bukit. This is the process of purifiying the protagonist, Barman. The portrayal of Barman as 
a character who fails to fulfil his duty as a husband is actually a depiction of the suffering of a human being who feels pressured to look for a solution to his problems. This depiction or suffering is already evident before the meeting between Barman and Humam. The meeting brings to a climax the meaning of Barman"s emotional suffering, that is, "his state of being bound to this world", the remedy of which is the dissolution of the self. Barman's unrelenting effort to overcome his suffering in order to find "pure and eternal peace" is rewarded, for example, through his climb up the hill which results in his chance meeting with Humam. Below is the excerpt from Khotbah di Atas Bukit:

"Kita akan melakukan perjalanan," kata Barman pada kelompok yang mendengarkannya. "Perjalanan kita akan sepenting perjalanan hidup seluruh manusia. Perjalanan para nabi, orangorang arif, para filsuf."

Mereka mendengarkan. Saling pandang.

"Ke mana, Bapak?"

"Bukit. Ke sana!" Barman menunjuk dengan jarinya.

"Kita akan mendaki. Siapkanlah."

“Kapan?”

"Besok pagi. Dan hanya mereka yang ingin mendapat jawaban diperkenankan ikut."

"We will go on a journey," says Barman to those who are listening to him. "Our journey will be as important as the lives of the entire human race. The journey of the prophets, the wise and the philosophers."

They continue to listen. They look at one another.

"Where to, sir?"

"The hills. There!" Barman points with his finger.

"We will climb them. Make preparations." 
"When?"

"Tomorrow morning. And only those who are looking for the answer may come along."

(Kuntowijoyo, 2000:208)

What Barman means by "perjalanan" in the phrase "perjalanan penting yang dilalui para nabi" (an important journey undertaken by the prophets) is the spiritual journey to meet the Creator. This is reinforced in the sentence "liburan Barman menjadi perburuan spiritual yang indah" (Barman's vacation becomes a beautiful spiritual quest) in the blurb of the novel. It is important to remember that one's meeting with God and one's love for Him are the underpinnings of tauhid. Therefore, Barman's "pencarian atau pendakian" (quest or climb) is a spiritual journey in search of the Almighty.

In assigning meaning to the symbols in the novel Khotbah di Atas Bukit, it must be stressed that the use of symbols centres around three sources, the Qur'an, the Hadith (the legal ways Prophet Muhammad SAW) and the divine inspirations of the anbiya (the prophets) as well as sufi masters. As the late Kuntowijoyo himself had said in an interview on 25 Mei 2003, to understand sufi works, the same spiritual exploration must take place within the reader or critic himself. Similar views are found in writings that stress the importance of understanding the author's background because the writer had undergone a heightened purification of the soul and a great spiritual experience. In this respect, only researchers who can put thimselves in the author's shoes will be able to correctly interpret the symbols (S.M Zakir, 2000:105-06).

It must be emphasized that the symbols employed in Khotbah di Atas Bukit are sourced from Javanese sufism or kejawen. ${ }^{9}$ The symbols are presented for two purposes, to be interpreted and to make the reader understand the various aspects of sufi teachings. This means that the symbols found in Khotbah di Atas Bukit, as explained above, are not intended merely to embelish the literary work but also to exemplify the author's transcendental doctrine. In other words, the symbols in Khotbah di Atas Bukit are not empty symbols. Clearly the composition of the text Khotbah di Atas Bukit by Kuntowijoyo conforms to the characteristic features of the theory 
of Transcendental Literature which he himself had put forward. Among the most obvious of these features in the novel is the use of symbols to explain the essence of sufi teachings.

\section{Perennial Philosophy Issues in Khotbah di Atas Bukit}

According to Budhy Munawar Rachman (1994), ${ }^{10}$ the works of writers of the Transcendental Literature school can be understood using the perennial philosophy of Frithjof Schuon, a Muslim Swiss philosopher. Frithjof Schuon, whose Muslim name is Muhammad Isa Nuruddin, had first undertaken an "intellectual journey" by studying various philosophies and religions before finally embracing Islam. Other than Frithjof Schuon, a well-known and influential Indonesian intellectual, Nurcholish Majid, is also said to have accepted the inclusivism and tolerance practised in Islam which keeps its door of communication open to people of other faiths and philosophical teachings. Clearly, Schuon and Majid encourage religious toleration among the various religions in order for the truth of Islam to shine in the final reckoning, after comparisons have been made.

The perennial philosophy linked to Frithjof Schuon, among other things, acknowledges the "transcendental unity of religions". This means that the various religions are seen to have some common ground or a basic meeting point. In order to understand what is meant by common ground, there is an analogy which likens the various religions and faiths in the world to lights of multifarious hues. There are, for example, the colours red, yellow, green, and white. The dissimilarities between the light rays lie only in their "colour quality" which is perceptible to the human eye. However, they all share a basic similarity, that is, they are all colours (Komaruddin Hidayat, 1992:84-85).

In this case, according to Schuon, the religions and spiritual traditions of this world all originate from a primordial religion which has shaped the intellectual and spiritual heritage of primitive man. This primordial religion is known as the original religion of self. To arrive at this point, one needs to first understand that there is a deeper side to meaning, which is referred to as esoteric meaning. All religions and spiritual traditions are moving towards nature, or towards the origin of creation, or that which is eternal. The different paths or approaches taken by the various religions (the different 
colours) will not destroy the objective we wish to achieve (the light). Perennial philosophy, according to Schuon, can be the discourse of "teologi dan fenomenologi sekaligus" (theology and phenomenology simultaneously) (Budhy Munawar Rachman, 1994:11-12) ${ }^{11}$.

In Khotbah di Atas Bukit, the part where Barman speaks to his friends and relatives as he sits straddling his horse, can be linked to the basis of perennial teachings. Barman, smilingly, places "Budha, atau Yesus, atau Muhammad" (Buddha, or Jesus, or Muhammad) on the same plane (Kuntowijoyo, 2000:232). In the following paragraph, more evidence of perennial philosophy can be found in Khotbah di Atas Bukit:

Barman mempelajari kejadian yang menimpanya. la ingin menafsirkan hidupnya. Seandainya Humam masih dapat diajak bicara, laki-laki tua sebaya itu pasti akan menuturkan lagi kebijaksanaan-kebijaksanaan. Masihkah engkau suka memancing di duniamu yang baru, Humam? Barman mencoba memahami jalan yang telah ditempuh oleh Humam. Jalan untuk hidup dan jalan untuk menghentikan hidup itu. Lebih dari buku-buku yang pernah dibacanya: Talmud, Injil, Qur'an, Das Kapital, riwayat orang-orang besar, bintang film; dia mengagumi Humam.

(Barman tries to learn from the affliction that has befallen him. He wants to analyse his life. If only he can get to talk to Humam, the old man who is about his age would surely dish out more pearls of wisdom. Do you still like fishing in your new world, Humam? Barman tries to understand the road that Humam has taken. A road for living and a road to stop living. Better than the books he has ever read: the Talmud, the Bible, the Qur'an, Das Kapital, the biographies of great people, the film stars: he is fascinated with Humam).

(Kuntowijoyo, 2000:150)

In the above paragraph, Barman links Humam, his spiritual guru, to "wisdom". Accoring to Barman, Humam'a wisdom transcends everything he has ever read including in the Talmud, the Old Testament, the Qur'an and the Das Kapital. The Talmud obviously symbolizes Judaism, the Bible, Christianity; the Qur'an is the symbol for Islam while the Das Kapital, Karl Marx's work, represents the absence of religious belief. This, for instance, is in accordance with perennial teachings which stipulate that all religions and spiritual 
traditions are geared towards fitrah or the origin of creation. In this respect, the "hill" on which Humam lives (which represents wisdom) surpasses all religious symbolism. This paragraph corresponds to the author's earlier description of the character Humam. During their first encounter, the mysterious Humam states that, "aku sebenarnya tak lagi punya nama, aku hanyalah sesuatu seperti yang lainnya, di sini, nama tak ada gunanya" (Actually, I no longer have a name, I am like all the rest, here names serve no purpose"] (2000:69). Indirectly, Kuntowijoyo is saying that the different paths or approaches taken by the different religions do not destroy the objective (in this case, the "wisdom" on the "hill"). Names, religions, and holy books are no longer meaningful because Humam, who "takes care of the hill" feels that the only thing that exists is the Creator, or the power of tauhid, or the Transcendental Source.

Among the other teachings in perennial philosophy is that desire and possession are the causes of all human sufferings which arise due to attachment. This bond is the root cause or the reason man distances himself from the Almighty. Kuntowijoyo depicts the character Barman as a symbol of human beings who are always looking for "possession". Barman who is old is painted as someone who is still searching for happiness in this world. This short-lived happiness is embodied in the character Popi who symbolizes desire (in this case, sexual desire as Barman is impotent). Her unfulfilled desire is the reason for the suffering. In order to provide a transcendental solution, the character Humam is created in Khotbah di Atas Bukit to help Barman disengage himself from his "attachment". The brief appearance of Humam causes Barman to be confused. However, once Humam is gone, Barman himself finds the "eternity" he longs for, that is, his union with the Transcendental Power. Perennial philosophy teaches that every form of traditional art possesses the principles of truth and beauty. This philosophy also criticises modern technology which it considers the cause of the destruction of the human soul to the extent that human beings lose their God, meaning, as well their aim in life (Budhy Munawar Rachman, 1994:12-16).

As a researcher who studies the works of the proponents of transcendental literature, Budhy comes to the conclusion that the school of Transcendental Literature is capable of bringing about "changes in Islam" and endowing it with its very own unique 
characteristics. This school of thought emphasizes that the quality of literary works is closely related to the author's level of spiritual development. This means that the creative process of the author is closely linked to his spiritual experience. Budhy's opinion is given below:

... yang disebut aliran sastra transendental atau yang dikenal juga dengan sastra sufi yang dipeloporioleh karya-karya dari Abdul Hadi WM, Kuntowijoyo, Sutardji Calzoum Bachri, Danarto, Fudoli Zaini dan sebagainya. Aliran ini sangat khas dalam pengertian sangat sarat dengan muatan religius, bahkan sangat mengandaikan proses kreatif dan perkembangan atau kematangan spiritual dari sastrawan yang menulis karya sastra. Dengan kata lain mutu dari sastra itu sangat tergantung dari tingkat perkembangan spiritual pengarang.

... that which is referred to as Transcendental Literature, or also known as sufi literature, is pioneered by such writers as Abdul Hadi WM, Kuntowijoyo, Sutardji Calzoum Bachri, Danarto, Fudoli Zaini and others. This school of thought is unique in the sense that the works of its writers are laden with religious content. This movement, in fact, presupposes the creative process and the spiritual development or maturity of the writer producing the literary works. In other words, the quality of literary works depends very much on the author's level of spiritual development.

The role of perennial philosophy in the work of Kuntowijoyo needs to be assessed. His zeal in incorporating elements of perennial philosophy in his work causes him to place the Qur'an on the same level as the "Talmud, Injil, Das Kapital, riwayat orangorang besar, bintang film" (the Talmud, the Bible, Das Kapital, the biographies of great men, film stars ...). This raises a number of questions. In addition, the author also counts "Buddha, Yesus, dan Muhammad" (Buddha, Jesus and Muhammad) among the people who "harus berdiri di sini" (should be standing here) in the context of this research, the hill, "dan mengucapkan sesuatu" (and say a few words) that is, a sermon full of wisdom.

As this philosophy places all religions on the same level, it is often viewed negatively. Critics of Perennial Philosophy consider the essence of this philosophy to be against the concept of tauhid 
in Islam. In this respect, Kuntowijoyo regards the "Talmud, the Bible, the Qur'an, Das Kapital, the biographies of great people, of film stars" as the same "book". He also clearly states in the text that "Buddha, Jesus and Muhammad" are religious leaders who "memiliki kebijaksanaan yang sama" (possess the same kind of wisdom). Both these findings in Khotbah di Atas Bukit are in line with global theology or global religion.

This idea can be traced to the Christian theologist Wilfred Cantwell Smith who wrote the book The Meaning and End of Religion (1978). ${ }^{12}$ In essence, Smith is of the opinion that religion is only the point of view of one person. Since it is merely a point of view, there is no such thing as a religion. Smith replaces the term "religion" with "cumulative tradition" (the traditions of people in history that have been compiled, including myths and religious rituals of the Hindus, Buddhists, Muslims and Christians, for example). The term "faith" is defined by Smith as a spiritual experience of a personal nature. This new idea, according to Smith, could be an alternative credence which anyone can embrace, regardless whether he has faith or does not, whether he is a sufi, Marxist, Muslim, or Christian, and so on. According to the followers of this belief,,$^{13}$ this theory offers peace of mind which no religion can offer. This is because "every major religious tradition includes its justifications for violence". In other words, the religions that exist today justify violence and the killing of one another (Kurtz, 1995: 215-16).

Kuntowijoyo has put forward the theory of global theology or global religion. The principles of this theory can be repudiated by going back to the two main sources of knowledge in Islam, the Qur'an and the Hadith. In relation to this, Allah clearly states that the Qur'an is not "merely a book" but a "book of truth". In verse 213, Surah al-Baqarah, Allah says (which can be translated as):

Mankind was one community and Allah sent Prophets with glad tidings and warnings, and with them He sent down the Scripture in truth to judge between people in matters wherein they differed. And only those to whom (the Scripture) was given differed concerning it after clear proof had come unto them through hatred, one to another. Then Allah by His Leave guided those who believed to the truth of that wherein they differed. And Allah guides whom He will to the Straight Path.

In verse 32, Surah al-Anfal, the truth of the Qur'an is upheld. 


\section{MALAY LITERATURE}

The verse can be translated as:

And (remember) when they said: O Allah! If this (the Qur'an) is indeed the truth (revealed from You, rain down stones onto us from the sky, or bring on us a painful torment.

At the same time, the Qur'an also reminds us that in this world there are those who have faith and those who do not. In verse 99, Surah Yunus, Allah says (which can be translated as):

And had your Lord willed, those on earth would have believed, all of them together! So, will you (O Muhammad pbuh) then compel mankind, until they become believers?

In line with this, the "equality of religions" can also be refuted based on the actions of Rasulullah SAW who punished a companion who had reverted to the Christian faith after the first hijrah (emigration) to Abyssinia. Rasulullah SAW also ordered the wife of this companion to seek divorce from her husband. Aside from this, the Qur'an also outrightly rejects the idea that Jesus was the son of God, as is believed by the Christians. In verses 89-92, Surah Maryam, Allah says (which can be translated as):

"Indeed you have brought forth (said) a terrible evil thing! Whereby the heavens are almost torn, and the earth is split asunder, and the mountains fall in ruins, that they ascribe a son) to the Most Gracious. But it is not suitable for (the Majesty of) the Most Gracious (Allah) that He should beget a son (or offspring or children)."

Apart from this, putting Islam on the same plane as the other religions is not accurate at all. In verse 19, Surah al-Imran, Allah says (which can be translated as):

"Truly, the religion with Allah is Islam ...."

The word "Islam" as used in the verse above is preceded by the Arabic letters alif and lam, the combination of which forms 'al' which from the point of view of Arabic grammar, is an isim makrifah (definite article), and not an isim nakirah (indefinite article). Thus, the word al-Islam in the verse above is categorized as a proper noun, in other words, a name, and one that is given by Allah to his religion which He clearly states in verse 3, Surah al-Ma'idah (which can be translated as): 
... This day, those who believed have given up all hope of your religion; so fear them not, but fear Me. This day, I perfected your religion for you, completed My favour upon you, and have chosen for you Islam as your religion.

This study finds that it is difficult to determine Kuntowijoyo's true stand in the matter because of the symbolism he uses. If Khotbah di Atas Bukit is intended to incorporate the teachings of global theology, it is clear that this goes against the concept of tauhid and walayat Tuhan (the authority of God), as pointed out earlier. However, if Kuntowijoyo merely wishes to present the concept of al-wujud al muqayyad which is advocated by Sufism as discussed earlier, then this is acceptable. ${ }^{14}$ This is because wujud al muqayyad stresses that Zat Tuhan (the nature of God) will never be known by man. Knowledge of Allah can only be acquired by learning about His characteristics. The Oneness of God, the basis of tauhid, is a characteristic of Allah. The characteristic shows the One who is characterized because it is from knowing this characteristic that we learn about the existence of Allah. Knowledge of this is known as la'la an-nur (blinking light) which shines from al-ahadiyyah (Oneness that is Most Specific) in the signs of the existence of Prophet Muhammad SAW. This light can only be perceived through the characteristics mentioned (in this case, signs). Verse 93, Surah an-Naml, for example, is evidence for the argument relating to these signs. The verse can be translated as:

And say (O Muhammad pbuh): "All praise and thanks be to Allah. He will show you His Ayat (signs, in yourselves, and in the universe or punishments), and you shall recognize them. And your Lord is not unaware of what you do.

The signs to be interpreted become symbols, or mystical expressions such as syatihat. In literary works, these signs are "characteristics" which signify "the Characterized". The following paragraph is evidence that the character Barman who manages to "conquer the hilltop" and learns about the existence of "Humam, the keeper of the hill", is at peace to the extent that he feels he has turned into light, like a firefly:

Biarlah, ia bukannya mencari ilmu, tetapi kebijaksanaan. Betapa ia berbahagia! Pengasingan yang sempurna! la selalu tersenyum: di 


\section{MALAY LITERATURE}

bawah sana dunia yang ribut, kerumunan yang tak berjiwa. Dan di sini, memancar-mancar cahaya! Dibayangkannya dirinya sebagai kunang-kunang tunggal yang berkeliling di tengah batang-batang padi yang gelap. la suka gambaran itu. Kenangannya pada kunang-kunang di sawah menjadi indah. Ya, akulah kunangkunang itu! Sendiri, tetapi tak jemu berkedip.

(Let him be, he is not on a quest for knowledge but for wisdom. How happy he is! A perfect isolation! He smiles frequently: down there the world is chaotic, a swarm devoid of soul. And here, the light is brilliant! He imagines himself as a lone firefly, darting about among dark paddy stalks. He likes the image. His memory of fireflies in the rice-fields suddenly becomes pleasant. Yes, I am those fireflies! Alone, but untiringly flickering).

(Kuntowijoyo, 2000:151)

The study finds that Kuntowijoyo merely wishes to present the abstract world (a literary work full of meaning but veiled by symbolism) in order to understand the concrete world (the relationship between the self and knowledge of the self to achieve effacement). This argument is put forward because, in order to understand the meaning behind the symbols presented, interpretations and inferences (tafsir dan ta'wil) based on the writer's personal opinions and his background, must be attempted. In an article in the Harian Kompas dated 24 August 2000, titled "Selamat Tinggal Mitos", Kuntowijoyo criticizes certain kejawen traditions, and the obsession of Indonesians with superstitions and myths. According to him, such beliefs have influenced the people's thinking. Kuntowijoyo is also of the opinion that such myths have led the people to avoid leading real lives and instead live in an abstract world full of symbols. In the article, Kuntowijoyo demands that the people discard this way of thinking which is steeped in myth, and change to a way of thinking that is rooted in concrete reality.

The arts is a medium we can use to detach the public's mind from myth, and to change their thinking. According to Kuntowijoyo, the arts does the opposite for the masses, that is, it further enhances their abstract values which are then manifested in other forms of art. This means that by doing so, the artist invites society 
to place some importance on makna nilai (the "meaning of values") in a literary work. Thus, in order to lead people or readers in this direction, Kuntowijoyo deliberately introduces external influences (in this case, kejawen teachings and myths with an Islamic flavour) as symbols, as well as sensational elements to capture the reader's attention. It is in this context that his use of myth needs to be properly understood. A more lengthy explanation of this can be found in Kuntowijoyo's other writings, such as in the Harian Republika (1998). According to him, the incorporation of elements of kejawen in literary works is aimed at illustrating the use of typological or local references to attract readers who are familiar with the kejawen tradition. This, according to Kuntowijoyo (1984:127-28) will facilitate the sending of transcendental messages through literature as the "outside influences" are already known to society. ${ }^{15}$ In this case, the element of inclusivism adopted from the teachings of kejawen and the elements of myth presented in Khotbah di Atas Bukit are a challenge for the sufis. It must be remembered that Barman himself is the very image of a priyayi abangan who is awakened by his meeting with the mysterious Humam, who represents the santri.

Based on the arguments above, it is difficult to positively link Kuntowijoyo to global theology, a belief held by adherents of Liberal Islam in Indonesia. Nevertheless, this study cannot refute that Khotbah di Atas Bukit may cause confusion among readers who fail to interpret the symbols correctly. This confusion may lead readers to make the wrong interpretations, resulting in an obscure perception of tauhid (Islamic Monotheism or the Oneness of Allah) in Islam. Obscurity in aspects of aqidah (faith) will render a particular piece of work a futile effort as the main aim of Islamic literature is to exalt tauhid (the Oneness of Allah), prophethood and the authority of those who have iman.

\section{Conclusion}

It cannot be denied that Khotbah di Atas Bukit aims to ennoble the concept of tauhid. It begins as a serial novel. The text presents characters who are "shrouded in mystery" to evoke mystical teachings in Islam. Kuntowijoyo's Khotbah di Atas Bukit was written to foreground transcendental principles. These transcendental principles or principles of faith in Allah, however, are not presented 
in the form of a discourse or sermon. Instead, they are incorporated in the work through symbolism. Therefore, the work is not to be read using the normal approach. It requires some analysis and interpretation (ta'wil). The character Barman, for example, is the symbol of a priyayi who finds in Humam a santri full of mystery. Barman is taught the basics of sufism, such as foregoing luxury and the pleasures of this world in order to attain the love of God. The character Popi, Barman's young wife, can be interpreted to symbolize "fleeting pleasure", that is, "worldliness".

As a novel that leans towards sufism, Khotbah di Atas Bukit is adept at manipulating symbols. Barman experiences "suffering" and ends with his "dissolution and a meeting with Allah, the Beloved". To discuss the issues of faith and tauhid, Kuntowijoyo uses local sources, that is, kejawen (also referred to as Javanese sufism). This study finds that since Kuntowijoyo's source of reference is not particularly clear, there is ambiguity in the text to the extent that it may affect the aspects of tauhid he aims to present. In his effort to introduce sufism, Kuntowijoyo has conveyed the wrong meaning, and may end up promoting global theology where tauhid is simplified and religions "combined". In addition, Khotbah di Atas Bukit is a complex novel to read because of the overuse of symbols, which tend to obscure meaning. This kind of symbolism requires analysis, especially for readers who have little or no knowledge of Sufism. It is this which makes Khotbah di Atas Bukit a specialized piece of work for a specialized readership.

\section{Notes}

1. See also Wan Mohd Mahyiddin, 1996, pg. xiii. The author writes that the coming of Islam with its unique concept of tauhid, brought to the forefront extraordinary leadership qualities.

2. The discussion concerning following the leadership of Allah or that of taghut is also dealt with in some depth in discourses on Hizbullah (the followers of Allah) and Hizbusshaitan (the followers of shaitan). Abdul Hadi Awang, for example, stresses the leadership or authority of shaitan citing pre-Islamic leaders such as Firaun, Namrud, Haman and Qarun as examples. Abdul Hadi mentions that verse 55 of Surah al-Ma'idah, is also called ayat wilayah: "... and the believers,- those 
who establish regular As-Salat (prayers), and give Zakat, and they bow down or submit themselves with obedience to Allah in prayer)" contains the qualities of leadership that should be emulated. Refer to Abdul Hadi Awang, 2003, pg. 148-83, especially pg. 156-57.

3. The distinctions between santri and abangan has been discussed in great detail by Zaini Muchtarom, among others. In his research, he explains how an oritentalist named Clifford Geertz in his book The Religion of Jawa, had divided the population of Java into three groups: the santri, abangan and priyayi. The santri and abangan, according to Zaini, are categorised according to their "religious practices". The guru pesantren, also known as guru sekolah agama, i.e religious teachers, are referred to as kiyai. Another term for santri is putihan (because of their white skullcaps). After they have performed the hajj, they are called kaji (an acronym for kopyah haji). According to Zaini again, a simple way of defining santri is to term them as "students of pesantren, pondok, rangkang meunasah or surau", in other words, students of religious schools' who are devoted to Islam. The abangan, on the other hand, rarely perform Islamic acts of worship and still cling to Hindu-Buddhist beliefs, or other traditional beliefs although they have already converted to Islam. This happens because pre-Islamic influences were extremely strong among the abangan. See Zaini Muchtarom, 1988, pg. 2.

4. See also Suwardi Endraswara, 2003, pg. 72-87. According to Suwardi, the form of mysticism known as kejawen was presented, among others, through wayang kulit (shadow play) and literary works. This is what is meant by cultural compromise. Cultural compromise resulted when Islam was spread through the local cultures. As a consequence of this compromise, many people in authority at the regional level were able to convert to Islam. However, this ruling class or priyayi, continued to practise certain old customs and Hindu rituals, while purporting to practice Islam. Through wayang kulit, for example, Islam was able to penetrate a part of the Javanese society. This approach is linked to the missionary efforts of the Wali Songo (nine holy men), particularly Sunan Kalijaga. Apart from wayang kulit, a literary form known as suluk was also a medium employed to spread Islam among the Hindus in Java. The mishmash of Islam and traditional beliefs, for example is clearly evident in Javanese classics such as Kitab Bonang, Suluk Sukarso, Suluk Wijil, Cabolek, Centini, and Hidayat Jati. The fall of Majapahit had caused the aristocrats and Javanese priyayi to lose their positions and livelihood. This group then turned 


\section{MALAY LITERATURE}

to the walis and religious teachers for attention to regain their status. The Majapahit Empire was replaced by the sultanate of Demak which had the backing of the religious teachers. Efforts to spread Islam were further undertaken using various artistic mediums including literature. This led to the introduction of kejawen teachings and literature which smacked of Islamic teachings. Mystical literature or sastera suluk, which is linked to the teachings of kejawen, began to flourish in Java and Islam became more widely accepted even though, as mentioned earlier, it gave rise to the evolution of the santri and abangan. See Simuh, 1995, pg. 17-20. See also Suripan Sadi Hutomo, 2001. This book focuses on the influence of kejawen in the oral literature of Java. For other sources, see Purwadi, 2003.

5. It must be stated here that the first mystical belief embraced by Ibnu Arabi, Hamzah Fansuri and Shamsuddin Pase was considered controversial and was rejected by a large number of ulama (Islamic scholars). Those who rejected this belief considered it deviant and capable of leading one to apostasy. See, for example, Kautsar Azhari Noer, 1995, pg. 4. Or see Ahmad Zuhairi, Hariza Mohd Yusof, Nizamiah Muhd Nor, Amalan Mistik dan Kebatinan Serta Pengaruhnya Terhadap Alam Melayu,1999, pg. 1-19 and 177-93. This book is a product of a study that rejects kejawen Islam and categorises this mystical Javanese teaching and influence, as deviant. The book also rejects the group wahdah al wujud (unity of creation) (see page 147), offering the explanation that "it is a depiction by some misguided people, and it can lead others astray. From a different perspective, the admission that everything that is worshipped is the truth is another form of wahdatul wujud, which presupposes that God exists in everything."

6. S.M. Zakir explains that the doctrine of Sufism has its own definition when it seeks to explain the concept of beauty. The true meaning of beauty in a piece of work is the beauty of the relationship between the servant (creation) and his Lord, Allah SWT. This relationship is translated through the representation of the mahhabat and habbat (the one who loves and the Beloved). Thus, it is the relationship between the one who loves and the Beloved that lends meaning to the concept of beauty in sufi teachings. In Sufism, there is this situation in which sufis are said to "be in a state of intoxication or are immersed in their own feelings (zauq)". This is said to happen, for example, when the "acts of remembering and bringing oneself closer to Allah SWT are done continuously through rigorous self-discipline and self-purification" such as the action of zikir (Islamic meditation). 
This process of immersion causes "mystical expressions to issue forth from the sufis who are experiencing zauq". Such mystical expressions are called shathiyat, from the root word shath. In the context of this study, Barman's character in Khotbah di Atas Bukit, is portrayed by the writer as having a special relationship with his "guru", Humam. This love relationship is a representation of mahhabat and habbat which sees Barman, in the end, fusing himself with his Creator. Throughout, Popi and Bobi (members of Barman's family) are always in a state of confusion because Barman is frequently uttering words and acting in a strange manner.

7. Alphabetic symbols are used whenever a sufi attempts to ascribe certain mystical meaning to an Arabic letter. Each Arabic letter is known to have an intrinsic numerical value. This is important in sufic spiritual practice as a tareqat teacher will apply this knowledge to determine the kind of wirid (repetitive recitation of given verses) suitable for a member of a sect. See Osman Bakar, 2003, pg. 363.

8. Birds (al-tayr) are among the most universal symbols used to represent the human soul.

9. There are many studies that show that the teachings of kejawen which are incorporated in art forms like tembang (a kind of song-like poetry), suluk and Javanese wayang (puppetry) are infused with the basic ideas of Islamic Sufism. For references that strengthen this opinion, see Suwardi Endraswara, 2003. See also Purwadi, 2003. The most well-known and authoritative study is that of Suripan Sadi Hutomo, 2001.

10. He is the Managing Director of the Lembaga Studi Agama dan Filsafat Jakarta.

11. For references on perennial philosophy, see Schuon's essay. Schuon, F, 1981, pg. 15-45. See also Schuon, F. 1976.

12. See also his writings in Smith, Wilfred Cantwell, 1959, pg. 56. See also, Smith, Wilfred Cantwell, 1962, pg. 131.

13. In Indonesia, the proponents of this global religion are linked to a group called Jaringan Islam Liberal (Liberal Islam Network). Among the main proponents of this school of thought is Nurcholish Madjid. See Greg Barton, Gagasan, 1999, or see also Nurcholish Madjid, 1995, pg. xxvii. 


\section{MALAY LITERATURE}

14. The concept al-wujud al muqayyad in sufi teachings is based on the sayings of Sayyidina Ali in his sermon at-Tatanjiyah: "Whosoever knows his God, he knows himself." In this matter, Sayyidina Ali stressed that a person who knows himself, that is, who knows where he comes from, and where he will be going, and this knowledge is based on the true knowledge, then he will be able to face maujudat (the end of everything that exists). See Lawson B. Todd, 2003, pg. $452-480$.

15. For a deeper understanding of this issue, refer to Wiryamartana I Kuntara, 1990.

\section{References}

Abdul Hadi Awang, 2003. Islam: Fikrah, Harakah dan Daulah. Shah Alam: Dewan Pustaka Fajar.

Abdul Latif Muda \& Rosmawati Ali, 1998. Pengantar IImu Tauhid. Kuala Lumpur: Pustaka Salam.

Ahmad Zuhairi, Hariza Mohd. Yusof \& Nizamiah Muhd Nor, 1999. Amalan Mistik dan Kebatinan Serta Pengaruhnya Terhadap Alam Melayu. Petaling Jaya: Tamadun Research Trust.

Al-Maududi, Sayyid Abul Ala, 1985. Asas-asas Islam. Translation by H.O.K Rahmat. Shah Alam: Dewan Pustaka Fajar.

Baharudin Ahmad (comp), 1992. Sastera Sufi. Kuala Lumpur: Dewan Bahasa dan Pustaka.

Baharudin Ahmad, 2003. "Sastra Melayu" in Nasr, Syed Hossein (comp.). Ensiklopedia Tematis Spiritualitas Islam. Bandung: Mizan.

Barton, Greg. 1999. Gagasan Islam Liberal di Indonesia. Jakarta: Paramadina.

Budhy Munawar Rachman, 1994. "Puisi-puisi Perennial Emha Ainun Nadjib dan Pemikiran Islam Indonesia" in Horison July: 11-12.

Carl W, Ernst \& Nasr, Sayyed Hossein (comp.), 1994. Words of Ectasy in Sufism. New York: State University New York.

Kautsar Azhari Noer, 1995. Ibn al-Arabi. Jakarta: Paramadina.

Komaruddin Hidayat, 1992. "Schoun Nasr dan Cak Nur" in Jurnal Ulumul Quran III (1): 84-85. Jakarta: t.pt 
Kuntowijoyo, 1982. "Saya Kira Kita Memerlukan Juga Sebuah Sastra Transendental" in Berita Buana 21 Disember: 4.

Kuntowijoyo, 1984. "Penokohan dan Perwatakan" in Ady Zoeltom (ed.). Sastera Indonesia dalam Budaya Sastra. Jakarta: Rajawali.

Kuntowijoyo, 2000. Khotbah di Atas Bukit. Jogjakarta: Yayasan Bentang Budaya.

Kuntowijoyo, 2001. Muslim Tanpa Masjid. Bandung: Mizan.

Kuntowijoyo, 2000. "Selamat Tinggal Mitos" in Harian Kompas, 24 August.

Kuntowijoyo, 1998. Islamisasi Jawaisme. Harian Republika, 18 April.

Kuntowijoyo, 2003. Gagasan 'Sastra Transendental. Jogjakarta. Interview, 25 May.

Lawson, B.T., 2003. "Tempat Munculnya Cahaya-cahaya Kebenaran dari Rahasia llahi Dikaitkan dengan Amirul Mukminin oleh Rajab Bursi" (w.1411) in Nasr, Sayyed Hossein, C. Chittick., William \& Lewisohn, Leonard (Eds.). Warisan Sufi: Warisan Sufisme Persia Abad Pertengahan (1150-500). Jogjakarta: Penerbit Pustaka Sufi.

Lester R, Kurtz, 1995. Gods in the Global Village. Thousand Oaks: Pine Forge Press.

Mohd. Faizal Musa. 2010. "Sastera Islam: Fenomena, Wacana dan Penerapannya di Malaysia dan Indonesia." Thesis of Dr. of Phil, Institut Alam dan Tamadun Melayu, Universiti Kebangsaan Malaysia.

Muhammad Bukhari Lubis (comp.), 1997. "Hubungkait Sufisme dengan Puisi" in Kesusasteraan Islam: Sehimpunan Bahan Rujukan. Bangi: Taj Fikriyah Reprints.

Muhammad Taqi-ud-Din \& Muhammad Muhsin Khan, 1429 A.H. The Noble Qur'an: English Translation of the Meanings and Commentary. Madinah Munawwarah: King Fahd Complex for the Printing of The Holy Qur'an.

Nurcholish Madjid, 1995. Islam, Doktrin dan Peradaban. Jakarta: Paramadina.

Osman Bakar, 2003. "Tasawuf di Dunia melayu-indonesia" in Nasr, Syed Hossein. (comp.) Ensiklopedia Tematis Spiritualitas Islam, pg. 339-76. Bandung: Mizan.

Purwadi, 2003. Tasawuf Jawa. Jogjakarta: Penerbit Narasi. 
S.M. Zakir, 2000. "Pengucapan Shathiyat dalam Estetika Sufisme sebagai Model Estetika Sastera" in Pangsura January-June: 101-06.

Schuon, F., 1976. Islam and The Perennial Philosophy. Edinburgh: World of Islam Festival Publishing Company Ltd.

Schuon, F., 1981. "Understanding Esoterism" in Esoterism As Principle and As Way. Middlesex: Perennial Books Ltd.

Simuh, 1995. Sufisme Jawa Transformasi Tasawuf Islam Ke Mistik Jawa. Jogjakarta: Yayasan Bentang Budaya.

Smith, Wilfred Cantwell, 1959. "Comparative Religion: Whither and Why" in Eliade, Mircea, \& Kitagawa (eds.). The History of Religions: Essays in Methodology. Chicago: The University of Chicago Press.

Smith, Wilfred Cantwell, 1962. Patterns of Faith Around the World. Oxford: Oneworld.

Smith, Wilfred Cantwell, 1978. The Meaning and End of Religion. London: SPCK.

Suripan Sadi Hutomo, 2001. Sinkretisme Jawa-Islam. Jogjakarta: Yayasan Bentang Budaya.

Suwardi Endraswara, 2003. Mistik Kejawen: Sinkretisme, Simbolisme dan Sufisme dalam Budaya Spiritual Jawa. Jogjakarta: Penerbit Narasi.

Wan Mohd. Mahyiddin, 1996. Kepemimpinan. Shah Alam: Penerbit Fajar Bakti.

Wiryamartana I Kuntara. Arjuna Wiwaha: Transformasi Teks Jawa Kuno Lewat Tanggapan dan Penciptaan di Lingkungan Sastra Jawa. Jogjakarta: Duta Wacana University Press.

Zaini Muchtarom, 1988. Santri dan Abangan di Jawa. Jakarta: Indonesian Netherlands Cooperation in Islamic Studies (INIS). 